\title{
KOMPETENSI PENGADILAN NIAGA DALAM PENYELESAIAN SENGKETA BISNIS DI INDONESIA
}

\author{
Hotman Siahaan \\ Fakultas Hukum Universitas Palembang \\ Email : siahaanh38@gmail.com
}

\begin{abstract}
In the Indonesian justice system found three (3) judicial institutions authorized to settle economic disputes, the District Court, Commercial Court and the Court of Religion. With the presence of the three courts that settle economics disputes, it can also be compared the advantages and disadvantages from each judiciary in the resolution of economic disputes.Assessment implemented through legislation approach as normative legal research which is equipped with study of the principles of law, systematic legal, comparative law, and history of law.This paper find that the settlement of economics disputes through the Commercial Court is superior compared to the other court. Unfortunately, business dispute settlemet authority for the Commercial Court is still limited to bankruptcy issues and delays payment of debt obligations as well as certain disputes in the field of intellectual property rights. Considering the excellence of the Commercial Court in the resolution of economic disputes, it is better to extend the authority of the Commercial Court, including in the areas of tort and breach of contract for other business disputes.
\end{abstract}

Keywords: Commercial court; settle economic disputes

\section{ABSTRAK}

Dalam sistem peradilan Indonesia ditemukan 3 (tiga) institusi pengadilan yang berwenang menyelesaikan sengketa bisnis, yaitu Pengadilan Negeri, Pengadilan Niaga dan Pengadilan Agama. Dengan terdapatnya tiga lembaga pengadilan yang menyelesaikan sengketa bisnis, maka dapat pula diperbandingan kelebihan dan kekurangan masing-masing lembaga peradilan dalam penyelesaian sengketa bisnis. Pengkajian dilaksanakan melalui pendekatan perundang-undangan sebagai penelitian hukum normatif, dilengkapi dengan penelitian asas-asas hukum, sistematika hukum, dan perbandingan hukum serta sejarah hukum. Tulisan ini memaparkan bahwa penyelesaian sengketa bisnis melalui Pengadilan Niaga lebih unggul dibandingkan dengan pengadilan lainnya, namun kewenangan penyelesaian sengketa bisnis di Pengadilan Niaga saat ini masih terbatas pada masalah kepailitan dan penundaan kewajiban pembayaran utang serta sengketa tertentu di bidang hak kekayaan intelektual. Ada baiknya mengingat keunggulan Pengadilan Niaga dalam penyelesaian sengketa bisnis, kewenangan Pengadilan Niaga dapat diperluas termasuk dalam bidang wanprestasi dan perbuatan melawan hukum bagi sengketa bisnis lainnya.

\section{Kata Kunci: Pengadilan Niaga; Penyelesaian Sengketa Bisnis}

\section{PENDAHULUAN}

\section{Latar Belakang}

Penyelesaian sengketa bisnis melalui jalur litigasi melalui pengadilan merupakan tindakan ultimum remedium melalui peradilan yang berwenang. Ultimum remedium berarti merupakan tindakan terakhir yang dapat ditempuh apabila pihak yang bersengketa tidak dapat memperoleh penyelesaian secara kekeluargaan.

Sebagaimana pendapat M. Yahya Harahap bahwa peradilan masih tetap relevan sebagai the last resort atau tempat terakhir mencari kebenaran dan keadilan, sehingga secara teoritis masih diandalkan sebagai badan yang berfungsi dan berperan menegakkan 
kebenaran dan keadilan (to enforce the truth and justice). ${ }^{1} \quad$ Penyelesaian sengketa melalui pengadilan merupakan salah satu cara untuk menghindari eigenrehting, yang bertentangan dengan konsep negara hukum. Peradilan yang berwenang memeriksa dan mengadili sengketa secara litigasi hanyalah badan peradilan yang bernaung di bawah Mahkamah Agung.

Secara khusus, kekuasaan kehakiman telah diatur dalam Undang-Undang No. 48 tahun 2009 yang merupakan induk dan kerangka umum yang meletakkan asas-asas, landasan, dan pedoman bagi seluruh peradilan di Indonesia. Dalam hal mengadili setiap pengadilan mempunyai kewenangan tertentu atau kompetensi absolut (attributie van rechtsmacht).

Berkaitan dengan kompetensi absolut, yurisdiksi dalam hal penyelesaian sengketa bisnis secara litigasi ada pada Pengadilan Negeri, Pengadilan Niaga dan juga pada Pengadilan Agama.

Salah satu asas dalam pelaksanaan peradilan adalah sebagaimana yang dituangkan dalam Pasal 2 ayat (4) Undang-Undang Kekuasaan Kehakiman, yaitu; "Peradilan dilakukan dengan sederhana, cepat dan biaya ringan". Sebagai undang-undang yang menjadi payung hukum bagi peradilan, maka asas-asas yang terkandung dalam Undang-Undang Kekuasaan Kehakiman haruslah dapat diberlakukan dalam semua proses beracara di semua Pengadilan.

Bagi para pelaku ekonomi unsur kepercayaan (trust) merupakan hal penting di samping unsur kecepatan dan ketepatan. Pelaku ekonomi yang bergerak dalam lapangan bisnis sangatlah memegang teguh prinsip time is money ataupun prinsip nilai ekonomi atas waktu bagi ekonomi syariah. Dari ke tiga pengadilan yang berwenang menyelesaikan sengketa bisnis, dengan masing-masing kompetensi yang telah ditentukan oleh undang-undang, dapat dilihat dan diperbandingkan pengadilan manakah yang

\footnotetext{
${ }^{1}$ M. Yahya Harahap, 2008, Hukum Acara Perdata, Jakarta, Sinar Grafika, Cetakan ke delapan, hlm 229
}

lebih unggul dan sesuai dalam menerapkan asas peradilan sederhana, cepat dan biaya ringan dalam proses penyelesaian dan memutuskan sengketa bisnis.

\section{Metode Penelitian}

Guna mencari jawaban atas permasalahan di atas, maka tulisan ini menggunakan penelitian yuridis hukum normatif $^{2}$ dengan pendekatan perundangundangan (statute approach), ${ }^{3}$ Penelitian hukum normatif merupakan penelitian kepustakaan dengan menelaah peraturan yang berkaitan dengan Pengadilan Umum, Pengadilan Niaga dan Pengadilan Agama. Penelitian dilaksanakan melalui kajian terhadap bahan hukum primer, bahan hukum sekunder maupun bahan hukum tersier. Kajian pada bahan hukum sekunder berupa penelitian terhadap asas-asas hukum, penelitian sistematik hukum, penelitian taraf singkronisasi vertikal dan horizontal, serta melalui perbandingan hukum.

\section{Kerangka Teori}

Menurut Paton seperti dikutip Djuhaendah Hasan ${ }^{4}$ adalah, A principle is the broad reason, which lies at a base of a rule of law. Lebih lanjut disampaikan djuhaendah, "Asas adalah suatu alam pikiran yang dirumuskan secara luas dan mendasari adanya suatu norma hukum. Norma hukum adalah aturan dan aturan itu berdasarkan suatu asas. Asas memiliki sifat yang abstrak, sedangkan norma sifatnya kongkrit.

Asas adalah jiwanya norma hukum, sehingga apabila suatu norma hukum tidak berlandaskan suatu asas, norma itu kehilangan maknanya.

\footnotetext{
${ }^{2}$ Ronnyi Hanitijo Soemitro, 1990, Metode Penelitian Hukum dan Jurimetri, Jakarta, Ghalia Indonesia, hlm 11

${ }^{3}$ Peter Mahmud Marzuki, 2007, Penelitian Hukum, Jakarta, Cetakan Ketiga, Kencana Prenada Media Grup, hlm 92

${ }^{4}$ Djuhaendah Hasan, 2007, "Pembangunan Hukum Bisnis dalam Pembangunan Hukum Indonesia”, Dalam Pembangunan Hukum Bisnis Dalam Kerangka Sistem Hukum Nasional, 70 Tahun Prof. Dr. Djuhaendah Hasan, SH., Bandung: t.p., hlm 5.
} 
Menurut Djuhaendah Hasan kata ekonomi sepadan dengan kata "bisnis" memiliki arti suatu kegiatan/gerakan usaha atau aktivitas usaha dalam bidang perdagangan, industri berbagai produk baik barang maupun jasa serta pengelolaan dan perlindungannya ${ }^{5}$. Menurut Kartini Mulyadi, sengketa bisnis memang sulit untuk memberikan definisi yang tepat. ${ }^{6}$ Sengketa niaga yang dapat dimasukkan dalam kelompok sengketa bisnis adalah antara lain, 1) Permohonan pernyataan pailit, 2) Penundaan kewajiban pembayaran utang, 3) Sengketa yang berkaitan dengan Perseroan Terbatas dan atau organnya,4) Hal-hal lain yang diatur dalam buku kesatu dan buku kedua KUHDagang (seperti mengenai Firma, CV, Komisioner, Expeditur, Pengangkut), 5) Surat-surat Berharga (wesel, cek, surat sanggup, L/C), 6) Asuransi dan 7) Perkapalan, 8) Perbankan, 9) Pasar modal, 10) Hak kekayaan intelektual. ${ }^{7}$

Menurut Soerjono Soekanto; "Sengketa merupakan ketidakserasian antara pribadipribadi atau kelompok-kelompok yang mengadakan hubungan karena hak salah satu pihak terganggu atau dilanggar", ${ }^{\prime \prime}$ Tugas pokok pengadilan, yang menyelenggarakan kekuasaan kehakiman adalah untuk menerima, memeriksa dan mengadili serta menyelesaikan setiap perkara yang diajukan kepadanya. ${ }^{9}$ Salah satu asas dalam pelaksanaan peradilan adalah sebagaimana yang dituangkan dalam Pasal 2 ayat (4) Undang-Undang Kekuasaan Kehakiman, yaitu; "Peradilan dilakukan dengan sederhana, cepat dan biaya ringan".

Asep Iwan Setiawan menyatakan kata cepat menunjuk pada proses jalannya peradilan,

\footnotetext{
${ }^{5}$ Djuhaendah Hasan, op-cit hlm 3

${ }^{6}$ Kartini Muljadi, "Pengertian dan PrinsipPrinsip Umum Hukum Kepailitan”, dalam Rudhy A. Lontoh, dkk, 2001, Penyelesaian Utang-Piutang Melalui Pailit atau Penundaan Kewajiban Pembayaran Utang, Bandung, Alumni, hlm 82

7 ibid

${ }^{8}$ Soerjono Soekanto, 1979, Mengenal Antropologi Hukum, Bandung, Penerbit Alumni, hlm.26

${ }_{9}^{9}$ Sudikno Mertokusumo, 2002, Hukum Acara Perdata Indonesia, Yogyakarta, Edisi Keenam, Penerbit Liberty, hlm 75
}

terlalu banyak formalitas merupakan hambatan bagi pelaksanaan peradilan. Mengenai "cepat" dimaksudkan selekas mungkin namun dengan tetap memperhatikan ketelitian dan kecermatan. Dengan demikian pengertian cepat menjadi bagian dari pengertian sederhana. Kecepatan dalam memutuskan sengketa akan meningkatkan kewibawaan dan menambah kepercayaan masyarakat kepada pengadilan. ${ }^{10}$ Ditentukan biaya ringan agar terpikul oleh rakyat, biaya yang tinggi kebanyakan menyebabkan pihak yang berkepentingan enggan untuk mengajukan tuntutan hak kepada pengadilan. $^{11}$

Asas sederhana, cepat dan biaya ringan berkaitan dengan proses penyelesaian sengketa di pengadilan. Asas sederhana, cepat dan biaya ringan menghendaki berwujudan peradilan yang tidak berbeli-belit, tidak membuang waktu dan tidak membebani para justiabelen secara finansial, namun, tidaklah pula dimaksudkan bahwa hakim diperbolehkan meniadakan tata cara tertentu yang sudah ditetapkan undangundang, misalnya tidak menghiraukan cara-cara pemanggilan saksi maupun pihak yang berperkara sebagaimana diatur undang-undang.

Ahmad Mujahidin menyatakan yang dimaksud dengan asas sederhana, cepat dan biaya ringan adalah: ${ }^{12}$

a. "Sederhana, yaitu proses beracara dengan jelas, mudah dipahami dan tidak berbelitbelit serta tidak terjebak pada formalitasformalitas yang tidak penting dalam persidangan, sebab apabila terjebak pada formalitas yang berbelit-belit

\footnotetext{
${ }^{10}$ Asep Iwan Iriawan, 2010, Kajian Atas Kewenangan Pengadilan Niaga Dalam Penyelesaian Sengketa Bisnis Dihubungkan dengan Asas Kepastian Hukum sebagai Upaya Pengembangan Sistem Peradilan Indonesia, Disertasi, Program Studi Doktor Ilmu Hukum Program Pascasarjana Universitas Padjajaran Bandung, hlm 118

${ }^{11}$ Sudikno Mertokusumo, op-cit, hlm 36
${ }^{12}$ Ahmad Mujahidin, 2008, Pembaharuan Hukum Acara Perdata Peradilan Agama dan Mahkamah Syariyah, (lengkap dengan blanko-blanko), Jakarta, Penerbit IKAHI-MA-RI, hlm 9
} 
memungkinkan timbulnya berbagai penafsiran.

b. Cepat, yaitu dalam melakukan pemeriksaan hakim harus cerdas dalam menginventarisir persoalan yang diajukan dan mengidentifikasikan persoalan tersebut untuk kemudian mengambil intisari pokok persoalan untuk selanjutnya digali lebih dalam melalui alat-alat bukti yang ada. Apabila segala sesuatunya sudah diketahui majelis hakim, maka tidak ada cara lain kecuali majelis hakim harus secepatnya mengambil putusan untuk dibacakan di muka persidangan yang terbuka untuk umum.

c. Biaya ringan, yaitu harus diperhitungkan secara logis, rinci dan transparan, serta menghilangkan biaya-biaya lain di luar kepentingan para pihak dalam perkara, sebab tingginya biaya perkara menyebabkan para pencari keadilan bersikap apriori terhadap keberadaan pengadilan. Khusus persoalan biaya harus mengacu pada payung hukum tersendiri berupa peraturan pemerintah karena menyangkut mengenai penerimaan negara bukan pajak, melalui lembaga negara berupa pengadilan”.

\section{PEMBAHASAN}

Sengketa bisnis merupakan salah sengketa yang memerlukan upaya penyelesaian dalam waktu yang singkat. Sengketa bisnis, dapat diselesaikan secara litigasi sebagai ultimum remedium melalui peradilan yang berwenang atau mempunyai kompetensi untuk memeriksa dan memutus sengketa tersebut. Berikut penulis mencoba menjelaskan mengenai penyelesaian sengketa bisnis di Pengadilan Negeri, Pengadilan Agama dan Pengadilan Niaga:

\section{Penyelesaian Sengketa di Pengadilan Negeri}

Kewenangan Pengadilan Negeri sebagai peradilan umum adalah untuk memeriksa, mengadili dan memutus perkara pidana dan perdata sesuai dengan ketentuan peraturan perundang-undangan.
Perundang-undangan yang mengatur lingkungan Peradilan Umum adalah UndangUndang No. 2 Tahun 1986 yang telah dirubah dengan Undang-Undang No. 8 Tahun 2004 dan Perubahan Kedua dengan Undang-Undang No. 49 Tahun 2009.

Pengadilan Negeri memiliki kewenangan sebagai pemutus sengketa bisnis berdasarkan Pasal 50 UU No. 2 Tahun 1986 tentang Peradilan Umum yang menyatakan; "Pengadilan Negeri bertugas dan berwenang memeriksa, memutus dan menyelesaikan perkara pidana dan perkara perdata di tingkat pertama". Kewenangan Pengadilan Negeri tidak mengalami perubahan meskipun terjadi perubahan atas Undang-Undang No. 2 Tahun 1986 yaitu perubahan pertama dengan UU No. 8 Tahun 2004 dan perubahan kedua dengan UU No. 49 Tahun 2009.

Dalam penjelasan umum UU No. 2 Tahun 1986 angka 2 (dua) menyebutkan; "Pengadilan Negeri merupakan Pengadilan Tingkat Pertama untuk memeriksa, memutus, dan menyelesaikan perkara pidana dan perdata bagi rakyat pencari keadilan pada umumnya, kecuali undang-undang menentukan lain".

Sengketa bisnis sebagai bagian dari perkara perdata yang diperiksa dan diputus oleh Pengadilan Negeri di tingkat pertama dalam bentuk sengketa wanprestasi atau perbuatan melawan hukum.

Penyelesaian sengketa bisnis di Pengadilan Negeri berlaku hukum acara perdata dengan mewajibkan prosedur mediasi sesuai dengan SEMA No. 01 Tahun 2008 tentang Prosedur Mediasi di Pengadilan.

Penyelesaian sengketa perdata baik di peradilan umum, maupun peradilan agama, hakim berkewajiban untuk berupaya secara aktif mendamaikan para pihak seperti yang dimanatkan oleh PERMA No. 1 Tahun 2008 tentang Kewajiban Mediasi di Pengadilan. Pelaksanaan mediasi bersifat imperatif yang membawa konsekuensi ancaman kebatalan atas putusan pengadilan apabila mediasi tidak dilaksanakan. Kehadiran para pihak pada sidang pertama, dibebani dengan kewajiban 
melaksanakan mediasi pada hari itu juga atau paling lama 2 (dua) hari kerja berikutnya untuk berunding guna memilih mediator termasuk biaya yang mungkin timbul. Proses mediasi berlangsung paling lama 40 (empat puluh) hari kerja sejak mediator dipilih, dan dapat diperpanjang paling lama 14 (empat belas) hari kerja.

Dengan demikian proses mediasi berlangsung paling lama dalam waktu 54 (lima puluh empat) hari kerja. Uniknya meskipun mediasi terjadi setelah atau pada pelaksanaan persidangan pertama, namun Perma No. 1 Tahun 2008 tentang Mediasi menyatakan: "Jangka waktu proses mediasi tidak termasuk jangka waktu pemeriksaan perkara". Berarti akan cenderung lebih lama waktu yang diperlukan dalam memutuskan sengketa bila mediasi yang terjadi bersifat alot, kaku (deadlock) dan tidak berujung pada perdamaian, barulah dilaksanakan pemeriksaan mengenai substansi perkara. Keadaan ini menambah lama jangka waktu yang diperlukan dalam penyelesaian sengketa perdata secara litigasi di pengadilan, yang menyalahi asas peradilan secara cepat tersebut.

Tidak terlaksananya asas cepat dalam penyelesaian sengketa, menyebabkan biaya yang harus dipikul oleh pencari keadilan menjadi bertambah dan membengkak, ditambah lagi beban psikologis yang disebabkan lamanya memperoleh kepastian hukum.

Apabila upaya mediasi tidak membuahkan kesepakatan, berikutnya barulah sengketa diperiksa sesuai dengan surat gugatan dengan acara biasa berdasar tahapan penyelesaian sengketa perdata di pengadilan berupa:

1) Pembacaan gugatan;

2) Jawaban tergugat;

3) Replik;

4) Duplik;

5) Pembuktian;

6) Kesimpulan;

7) Musyawarah hakim dan Keputusan;

Atas keputusan pengadilan terhadap sengketa yang dimajukan para pihak, bila ada yang tidak puas dapat melakukan upaya hukum. Upaya hukum dimaksud upaya berjenjang berupa banding dan berikutnya kasasi serta peninjauan kembali yang relatif memakan waktu dan sering dijadikan sarana oleh pihak yang beriktikad tidak baik dalam mengulurngulur pelaksanaan putusan pengadilan.

Upaya hukum berjenjang diperlukan dalam rangka melakukan koreksi atas kemungkinan kesalahan atau kekeliruan putusan yang dibuat. Dalam penerapannya penggunaan upaya hukum yang berjenjang ini kurang selaras dengan kebutuhan para pelaku ekonomi khususnya berkaitan dengan tidak terselenggaranya asas peradilan sederhana, cepat dan biaya ringan. Keadaan ini sering dihindari oleh pelaku ekonomi atau bisnis yang enggan berurusan dengan "pengadilan" dan memilih penyelesaian sengketa secara nonlitigasi. Mereka menghindari pengadilan dengan menyepakati penyelesaian sengketa secara nonlitigasi, yang lebih menjamin penyelesaian sengketa secara sederhana, tidak berbelit, cepat dan biaya ringan.

\section{Penyelesaian Sengketa di Pengadilan Agama}

Kewenangan Pengadilan Agama untuk memeriksa, memutus dan menyelesaikan sengketa bisnis didasarkan pada pasal 49 Undang-Undang No. 3 Tahun 2006 tentang Perubahan atas Undang-Undang No. 7 Tahun 1989 tentang Peradilan Agama.

Menurut Pasal 49 UU No. 3 Tahun 2006 kewenangan Pengadilan Agama diperluas dengan penyelesaian sengketa bisnis syariah. Dengan demikian sengketa bisnis yang menjadi kewenangan Pengadilan Agama hanyalah bidang sengketa bisnis syariah, di luar itu tidaklah menjadi kewenangan Pengadilan Agama.

Penjelasan Pasal 49 huruf (i) UndangUndang No. 3 Tahun 2006 ekonomi syariah meliputi; perbankan syariah, lembaga keuangan mikro syariah, asuransi syariah, reasuransi syariah, reksadana syariah, obligasi syariah, dan surat berharga berjangka menengah syariah, sekuritas syariah, pembiayaan syariah, 
pegadaian syariah, dana pensiun lembaga keuangan syariah, dan bisnis syariah. Pasal 49 Undang-Undang Peradilan Agama ini telah memberikan kerangka dan batasan bahwa sengketa bisnis yang dapat dimajukan ke Pengadilan Agama hanyalah sengketa yang berkaitan dengan kegiatan ekonomi syariah. Kegiatan ekonomi syariah adalah kegiatan ekonomi yang berdasarkan prinsip-prinsip hukum Islam. Kompilasi Hukum Ekonomi Syariah juga menyebutkan bahwa pengadilan yang dimaksudkan adalah pengadilan/mahkamah syariah dalam lingkungan peradilan agama.

Hukum acara yang digunakan di lingkungan Pengadilan Agama pada dasarnya sama dengan hukum acara di Pengadilan Negeri namun hukum materil yang digunakan berbeda baik dalam pemeriksaan, menyelesaikan dan memutus sengketa bisnis syariah adalah hukum materil dengan prinsip hukum Islam seperti yang telah diatur dalam Kompilasi Hukum Ekonomi Syariah dan lainnya. Dengan demikian proses beracara, dan upaya hukum yang harus ditempuh dalam penyelesaian sengketa bisnis di Pengadilan Agama sama dengan proses beracara dan upaya hukum berjenjang yang terdapat di Pengadilan Negeri. Bila dicermati dari asas peradilan sederhana, cepat dan biaya ringan dalam penyelesaian sengketa bisnis di Pengadilan Agama belumlah dapat diwujudkan.

Rintangan yang menghalangi penerapan asas peradilan sederhana, cepat dan biaya ringan di Pengadilan Agama, selain berbelit-belit juga karena keharusan hakim untuk mengupayakan mediasi sebelum pemeriksaan substansi perkara dilakukan. Padahal sesungguhnya para pihak yang bersengketa memang sudah diketahui sebelumnya tidak lagi memerlukan upaya perdamaian dalam penyelesaian sengketa mereka. Bila dicermati dengan seksama asas kecepatan dari sisi waktu ini berbanding lurus dengan biaya yang dikeluarkan atau yang harus ditanggung oleh para pihak. Makin lama waktu yang dibutuhkan dalam penyelesaian sengketa, maka tentu akan semakin memperbesar pula biaya yang harus ditanggung.

\section{Penyelesaian Sengketa di Pengadilan Niaga}

Keberadaan Pengadilan Niaga merupakan pengadilan khusus dalam lingkungan peradilan umum. Berdasarkan Pasal 299 Undang-Undang No. 37 Tahun 2004 tentang Kepailitan dan Permohonan Penundaaan Kewajiban Pembayaran Utang menyatakan; "Kecuali ditentukan lain dalam Undang-Undang ini, maka hukum acara yang berlaku adalah hukum acara perdata". Frasa "kecuali ditentukan lain" mengandung arti bahwa proses penyelesaian sengketa di Pengadilan Niaga, apabila undang-undang telah menentukan secara khusus maka ketentuan hukum acara perdata secara umum dapat dikesampingkan. Dengan demikian dapat terjadi perbedaan proses beracara di Pengadilan Niaga sepanjang telah ditentukan oleh undang-undang. Hal yang membuat lain tersebut antara lain adalah:

a. Kewenangannya

$\begin{array}{cccr}\text { Untuk } & \text { saat ini yang menjadi } \\ \text { kewenangan } & \text { dari } & \text { Pengadilan } & \text { Niaga }\end{array}$ sebagaimana ditentukan undang-undang adalah perkara Permohonan Kepailitan dan Penundaan Kewajiban Pembayaran Utang, diatur dalam Undang-Undang No. 37 Tahun 2004. Sengketa lainnya adalah di bidang perniagaan yang penetapannya dilakukan dengan undangundang. Adapun perkara lain di bidang perniagaan adalah perkara di bidang Hak Kekayaan Intelektual, yaitu berupa sengketa Hak Desain Industri (UU No. 31 Tahun 2000), sengketa hak Desain Tata Letak Sirkuit Terpadu (UU No. 32 Tahun 2000), sengketa tentang Paten, ( UU No. 14 Tahun 2001), sengketa Merek (UU No. 15 Tahun 2001), sengketa Hak Cipta (UU No. 28 Tahun 2014).

b. Dibebaskan dari kewajiban mediasi

Sengketa bisnis yang diselesaikan melalui Pengadilan Niaga, meniadakan beberapa formalitas berdasarkan undang-undang sehingga asas peradilan sederhana, cepat dan biaya murah lebih dapat terwujud. Penyelesaian sengketa pada Pengadilan Niaga tidaklah menggunakan formalitas mediasi, hakim hanya 
berkewajiban menawarkan perdamaian dan jika para pihak tidak sepakat langsung dilanjutkan pada pemeriksaan sengketa. Jangka waktu proses beracara di Pengadilan Niaga telah ditentukan mengikat oleh undang-undang.

Apabila jangka waktu pemeriksaan perkara niaga yang ditentukan undang-undang, akan melampaui jangka waktu yang ditentukan haruslah dengan meminta persetujuan Ketua Mahkamah Agung.

Tabel : 1

Penerapan Mediasi dalam Penyelesaian Sengketa Perdata di Pengadilan

\begin{tabular}{|l|l|l|}
\hline No & Keharusan Mediasi & Mediasi dihapuskan \\
\hline 1 & $\begin{array}{l}\text { Semua sengketa } \\
\text { perdata yang diajukan } \\
\text { ke Peng. Tingkat } \\
\text { Pertama wajib lebih } \\
\text { dahulu diupayakan } \\
\text { penyelesaian } \\
\text { perdamaian dengan } \\
\text { bantuan mediator }\end{array}$ & \\
\hline 2 & & $\begin{array}{l}\text { Pengadilan Niaga } \\
\text { Pengadilan }\end{array}$ \\
& & $\begin{array}{l}\text { Hubungan Industrial } \\
\text { Keberatan atas } \\
\text { Putusan Komisi } \\
\text { Persaingan Usaha }\end{array}$ \\
\hline
\end{tabular}

c. Jangka waktu tertentu dalam setiap proses

Di Pengadilan Niaga, proses beracara dengan cepat telah dijamin oleh perundangundangan. Seperti meniadakan kewajiban mediasi, upaya hukum yang dipangkas dan jangka waktu proses beracara yang telah dibatasi oleh undang-undang. Jangka waktu proses beracara di Pengadilan Niaga telah ditentukan mengikat oleh undang-undang. Apabila jangka waktu pemeriksaan perkara niaga yang ditentukan undang-undang, akan melampaui jangka waktu yang ditentukan haruslah dengan meminta persetujuan Ketua Mahkamah Agung.

Penerapan waktu yang relatif cepat di Pengadilan Niaga karena telah dijamin oleh undang-undang, sehingga memberikan ketenangan dan kepastian waktu dalam penyelesaian sengketa, dan jaminan kepastian waktu ini tidaklah didapat dalam beracara di Pengadilan Negeri dan Pengadilan Agama.

Tabel 2

Jangka Waktu Putusan Sengketa Bisnis pada Pengadilan Niaga

\begin{tabular}{|c|c|c|c|}
\hline $\begin{array}{c}\text { Jenis } \\
\text { Sengketa }\end{array}$ & $\begin{array}{l}\text { Jangka waktu } \\
\text { (dihitung dari } \\
\text { pendaftaran } \\
\text { perkara) }\end{array}$ & Landasan & Keterangan \\
\hline Kepailitan & 60 hari & $\begin{array}{l}\text { Pasal } 8 \text { Ayat } \\
\text { (5) UU } \\
\text { No. } 37 \text { Th } \\
2004\end{array}$ & $\begin{array}{c}\text { Hari }=\text { hari } \\
\text { kalender }\end{array}$ \\
\hline Paten & 180 hari & $\begin{array}{l}\text { Pasal } 121 \\
\text { ayat (2) UU } \\
\text { No. } 14 \mathrm{Th} \\
2001\end{array}$ & $\begin{array}{l}\text { Hari }=\text { hari } \\
\text { kerja }\end{array}$ \\
\hline Hak Merek & 90 hari & \begin{tabular}{|c|} 
Pasal 80 ayat \\
(8) UU \\
No $15 \mathrm{Th}$ \\
2001
\end{tabular} & $\begin{array}{l}\text { Hari }=\text { hari } \\
\text { kerja }\end{array}$ \\
\hline Hak Cipta & 90 hari & \begin{tabular}{|} 
Pasal 61 ayat \\
(2) UU \\
No.19 Th \\
2002
\end{tabular} & $\begin{array}{l}\text { Hari }=\text { hari } \\
\text { kerja }\end{array}$ \\
\hline $\begin{array}{c}\text { Hak Desain } \\
\text { Industri }\end{array}$ & 90 hari & \begin{tabular}{|c|} 
Pasal 39 ayat \\
(8) UU \\
No.31 Th \\
2000
\end{tabular} & $\begin{array}{l}\text { Hari }=\text { hari } \\
\text { kerja }\end{array}$ \\
\hline $\begin{array}{c}\text { Desain Tata } \\
\text { Letak } \\
\text { Sirkuit } \\
\text { Terpadu }\end{array}$ & 90 hari & $\begin{array}{c}\text { Pasal } 31 \text { ayat } \\
\text { (8) UU } \\
\text { No.32 Th } \\
2000\end{array}$ & $\begin{array}{l}\text { Hari }=\text { hari } \\
\text { kerja }\end{array}$ \\
\hline
\end{tabular}

Sumber : Hasil penelitian dokumen oleh peneliti

d. Upaya hukum banding

Penanganan perkara dan penyelesaian sengketa menjadi relatif singkat di Pengadilan 
Niaga karena upaya hukum banding dipangkas dan dapat langsung upaya hukum kasasi ke Mahkamah Agung sebagaimana terlihat dalam tabel berikut:

Tabel 3

Jenjang Upaya Hukum Pada beberapa Pengadilan

\begin{tabular}{|c|c|c|c|}
\hline $\begin{array}{c}\text { Upaya } \\
\text { Hukum }\end{array}$ & $\begin{array}{c}\text { Pengadilan } \\
\text { Negeri }\end{array}$ & $\begin{array}{c}\text { Pengadilan } \\
\text { Agama }\end{array}$ & $\begin{array}{c}\text { Pengadilan } \\
\text { Niaga }\end{array}$ \\
\hline Banding & Ada & Ada & Tidak ada \\
\hline Kasasi & Ada & Ada & Ada \\
\hline $\begin{array}{c}\text { Peninjauan } \\
\text { Kembali }\end{array}$ & Ada & Ada & Ada \\
\hline
\end{tabular}

Sumber: hasil penelitian dokumen

\section{e. Pengunaan hakim ad-hoc}

Pada Pengadilan Niaga hakim ad hoc adalah seorang yang bukan berprofesi sebagai hakim, tetapi memiliki keahlian dalam menangani perkara niaga dan memenuhi persyaratan yang telah ditentukan untuk ditugaskan di pengadilan. Seorang hakim adhoc dapat merupakan pejabat pemerintah, pengacara, akademisi hukum atau pensiunan hakim, sehingga dipandang lebih dapat waktu meningkatkan kualitas putusan. Kualitas putusan juga didapatkan melalui kemungkinan bagi hakim untuk mengajukan pendapat yang berbeda (dissenting opinion).

Meskipun demikian kekurangan yang ditemukan pada Pengadilan Niaga adalah menyangkut kewenangan yang terbatas.

\section{PENUTUP}

Berdasarkan hasil penelitian dan pembahasan dapat ditarik kesimpulan, sebagai berikut:

1. Dalam proses beracara di Pengadilan Agama maupun Pengadilan Negeri, penerapan asas sederhana, cepat dan biaya ringan sulit diwujudkan karena tidak ada pembatasan waktu, prosedur yang berbelit dan upaya hukum yang berjenjang.

2. Pengadilan Niaga sebagai penyelesaian sengketa bisnis lebih unggul dalam menerapkan asas peradilan sederhana, cepat dan biaya ringan, dibandingkan dengan Pengadilan Negeri dan Pengadilan Agama. Proses peradilan dapat lebih cepat karena jangka waktu penyelesaian sengketa telah dibatasi, dibebaskan dari kewajiban mediasi serta dipangkasnya upaya hukum banding.

\section{DAFTAR PUSTAKA}

\section{Buku}

Mulyadi, Lilik, 2010, Perkara Kepailitan dan Penundaan Kewajiban Pembayaran Utang, Bandung: Alumni.

Marzuki, Peter Mahmud, 2007, Penelitian Hukum, Cetakan Ketiga, Jakarta: Kencana Prenada Media Grup.

Mertokusumo, Sudikno, 2002,Hukum Acara Perdata Indonesia, Yogyakarta: Penerbit Liberty.

Peorwadarminta, W.J.S, 1982, Kamus Umum Bahasa Indonesia, Jakarta: PN. Balai Pustaka.

Sutantio, Retnowulan, dan Iskandar Oeripkartawinata, 2002, Hukum Acara Perdata dalam Teori dan Praktek, Bandung: CV. Mandar Maju.

Harahap, M. Yahya, 2008, Hukum Acara Perdata, Jakarta: Sinar Grafika, Cetakan ke delapan.

Hasan, Djuhaendah, "Pembangunan Hukum Bisnis dalam Pembangunan Hukum Indonesia”, Dalam Pembangunan Hukum Bisnis Dalam Kerangka Sistem Hukum Nasional, 70 Tahun Prof.Dr. Djuhaendah Hasan, SH., Bandung: t.p.

Iriawan, Asep Iwan, 2010, Kajian Atas Kewenangan Pengadilan Niaga Dalam Penyelesaian Sengketa Bisnis Dihubungkan dengan Asas Kepastian Hukum sebagai Upaya Pengembangan Sistem Peradilan Indonesia, Bandung: Disertasi, Program Studi Doktor Ilmu Hukum Program Pascasarjana Universitas Padjajaran.

Mujahidin, Ahmad, 2008, Pembaharuan Hukum Acara Perdata Peradilan Agama dan Mahkamah Syariyah, (lengkap dengan 
Hotman Siahaan, Kompetensi Pengadilan Niaga Dalam Penyelesaian Sengketa Bisnis Di Indonesia Halaman 274-282

blanko-blanko), Jakarta: Penerbit IKAHIMA-RI.

Muljadi, Kartini, 2001, "Pengertian dan Prinsip-prinsip Umum Hukum Kepailitan”, dalam Rudhy A. Lontoh, dkk, Penyelesaian Utang-Piutang Melalui Pailit atau Penundaan Kewajiban Pembayaran Utang , Bandung: Alumni.

Soemitro, Ronnyi Hanitijo, 1990, Metode Penelitian Hukum dan Jurimetri, Jakarta: Ghalia Indonesia.

Soekanto, Soerjono, 1979, Mengenal Antropologi Hukum, Bandung: Penerbit Alumni.

Peraturan Perundang-Undangan

Undang-Undang No. 48 Tahun 2009 tentang Kekuasaan Kehakiman

Undang-Undang No. 37 Tahun 2004 tentang Kepailitan dan Penundaan Kewajiban Pembayaran Utang Undang-Undang No.2 Tahun 1986 Tentang Peradilan Umum Jo. Undang-Undang No. 49 Tahun 2009 tentang Perubahan Atas UU No. 2 Tahun 1986 tentang Peradilan Umum.

Undang-Undang No. 7 Tahun 1989 yang telah diubah dengan Undang-Undang No. 3 Tahun 2006 dan Perubahan Kedua Dengan Undang-Undang No. 50 Tahun 2009 tentang Peradilan Agama.

PERMA No. 1 Tahun 2008 tentang Kewajiban Mediasi

PERMA No. 2 Tahun 2008 tentang Kompilasi Hukum Ekonomi Syariah 